\title{
Liikkeenjohdon konsultointiin liittyvän tutkimustiedon hyödyntäminen
}

Heli Alén

Liikkeenjohdon konsultoinnin merkitys on yhteiskunnallisesti suuri, koska alan rakenne, laatu ja kehittyminen vaikuttavat voimakkaasti koko sen toimintaympäristöön. Yrityksillä on yhä voimakkaampi tarve keskittyä ydinosaamiseensa ja ulkoistaa muita toimintoja. Tämä näkyy myös kasvavana kiinnostuksena käyttää ulkopuolisia liikkeenjohdon asiantuntijoita. Alan kehittymisen keskeisinä tekijöinä ovat sitä koskeva tutkimustieto ja sen hyödyntäminen käytännössä.

Konsultin käsitettä ei ole yleisesti tarkoin määritelty ja myös käytännössä käsite on epämääräinen. PKT-säätiön määritelmän mukaan liikkeenjohdon konsultti on ulkopuolinen, yritystoimintaan vankasti perehtynyt asiantuntija, jolla on monipuolinen liikkeenjohdollinen koulutus ja kokemus. Konsultti työskentelee yritysjohdon apuna yrityksen johtamiseen liittyvissä kysymyksissä.

PKT-säätiön tehtävänä on edistää pk-yritysten kehittymistä ulkopuolisten asiantuntijoiden avulla. Yrityksiä halutaan kannustaa toimintojensa kehittämiseen, kannattavuuden parantamiseen ja kil- pailukyvyn lisäämiseen. Siinä yhtenä tärkeänä resurssina ovat konsultit. Tämä toimintamalli ei ole aina itsestään selvä varsinkaan pk-yrityksille. Säätiö neuvoo yrityksiä konsultin valintaan ja käyttöön liittyvissä asioissa. Oleellinen osa toimintaa on myös varmistaa sopivien ja pätevien liikkeenjohdon konsulttien saatavuus. Toimintaan kuuluu myös alan menetelmäkehitys ja konsulttien täydennyskoulutus. PKT-säätiö ei ole liikkeenjohdon konsulttien edunvalvontaorganisaatio, eikä säätiöllä ole jäseniä.

PKT-säätiö ylläpitää konsulttitietokantaa, jossa on noin 1000 suomalaisen liikkeenjohdon konsul- 


\section{KA T S A U K S I A}

tin taustatiedot erityisosaamisalueineen ja toimialapätevyyksineen. Myös konsulttien työkokemus, referenssit, koulutus ja muut pätevöitymistä kuvaavat kriteerit ovat selvitettävissä tietokannan avulla. Osaamista voi hakea joko henkilöittäin, konsulttiyrityksen mukaan tai konsulttiverkostoista. Tietokanta on tarkoitettu yritysten, koulutuslaitosten, julkisen sektorin organisaatioiden ja muiden konsulttien tarvitsijoiden käyttöön.

\section{TUTKIMUKSELLA ON SUORA YHTEYS KÄYTÄNTÖÖN}

Pyrittäessä edistämään konsulttien käyttöä yritysten resurssina on PKT-säätiön lähtökohtana ollut toisaalta hyvä konsultointialan tuntemus ja toisaalta alan kehittäminen. Tärkeää on myös tuntea konsulttien käyttäjäkuntaa. Näissä tarkoituksissa Turun kauppakorkeakoulun PK-Instituutissa tehtiin PKT-säätiön toimeksiannosta tutkimus (Boedeker, Hurmerinta-Peltomäki, Nummela: Asiantuntija - Apua! Asiantuntijapalvelut yrittäjän näkökulmasta. PKT-säätiön julkaisu 1/1995). Siinä selvitettiin, mitä asiantuntijapalveluja pk-yrityksille Suomessa tuotetaan, mitä palveluja pk-yritykset käyttävät ja miksi, mitä ne eivät käytä ja miksi, minkälaisia vaatimuksia pk-yrityksillä on asiantuntijapalveluille sekä miten näiden palvelujen tulisi kehittyä. Tutkimuksen lähtökohtana ovat pk-yrityksille suunnatut julkiset yrityspalvelut, mutta mukaan on otettu myös yksityisiä palveluja ja organisaatioita. Asiantuntijapalvelut jaetaan tutkimuksessa karkeasti kolmeen luokaan: koulutuspalvelut, konsultointi- ja neuvontapalvelut sekä tietopalvelut. Tutkimuksen aikana tuli esille kysymys siitä, onko asiantuntijapalvelujen kysynnässä kyse yrityksen ulkopuolisten palvelujen kehittämisprosessin nostamasta kysynnästä vai yrityksen oman kehitysprosessin herättämästä palvelutarpeesta? Tutkimuksen perusteella todetaan, että yrityksen kehittämistarve saa aikaan palvelutarpeen, joka voi kuitenkin jäädä huomaamatta ilman ulkopuolista palvelutarvekartoitusta tai aktiivista palvelujen markkinointia.

Toimiala ei voi kehittyä, ellei pohjana ole riittävästi tutkittua perustietoutta eikä alan menetelmäkehitystä pidetä määrätietoisena toimintana.

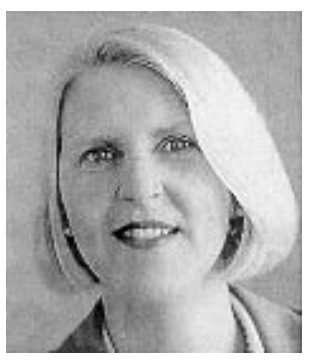

Heli Alén

Myös tulevaisuuteen suunnattua ennakointitietoa tarvitaan kehityksen ohjaamiseen. Niin Suomessa kuin kansainvälisestikin on alaa koskeva tutkimus ollut vähäistä ja painottunut lähinnä alalla toimiviin suuriin yrityksiin. Se antaa kuitenkin vaillinaisen kuvan käytännön todellisuudesta.

Liikkeenjohdon konsultoinnin historiaa, kehittymistä ja rakenteita kuvaava tutkimus on toiminut perustana alan ymmärtämiseen ja kehittämiseen. Paula Kyrö tutki vuonna 1995 PKT-säätiön toimeksiannosta tätä mielenkiintoista ja kehittyvää alaa tavoitteena tuottaa myös kansainvälisesti vertailukelpoista tietoa (Suomalainen liikkeenjohdon konsultointi. Toimialaraportti vuodelta 1994. PKTsäätiön julkaisu 2/1996). Aineisto koostui kyselytutkimuksesta ja Tilastokeskuksen aineistosta. Tutkimuksen tausta-aineisto ja käytetyt viitekehykset nojasivat Kyrön väitöskirjassaan tekemiin mallituksiin ja globaaliseen alan kartoitukseen.

Säätiö on hyödyntänyt toimialatutkimusta monella tavalla. Sillä on ollut vaikutusta säätiössä järjestettävään koulutukseen ja menetelmäkehitykseen ja se on ollut kannustimena ja pohjana jatkotutkimuksiin. Myös kansainvälisesti tutkimus on herättänyt mielenkiintoa alan organisaatioiden piirissä ja pk-järjestöissä, kuten eurooppalaisessa kattojärjestössä CESCE:ssa ( European Committee for Consulting Services ).

PKT-säätiö järjestää konsulteille ja yrityspalveluiden asiantuntijoille pääsääntöisesti lyhytkestoista täydennyskoulutusta. Koulutuksen tavoitteena ei ole kouluttaa alalle uusia konsultteja, vaan tarjota ajankohtaista ja täydentävää opetusta lähinnä pksektorin tarpeista johdettuna. Kuitenkin on kat- 
sottu tarpeelliseksi perehtyä toimialatutkimuksessa kuvattuihin konsultoinnin markkinakerrostumiin ja myös konsultoinnin arvoketjuun ja prosesseihin. (Ks. Paula Kyrön artikkeli tässä numerossa)

Laatuajattelu ja laatujärjestelmät ovat tärkeä osa konsultoinnin kehittymistä toimialana. Säätiö on pyrkinyt vaikuttamaan laatuaspektien kautta siihen, että yritykset voisivat käyttää konsultteja ja valita itselleen sopivan siten, että heillä olisi päätöksensä tukena joku konsultin toimintaa kuvaava laatumääre. Kysymys on äärimmäisen vaikea ja monimutkainen. PKT-säätiön konsulteille laatima laatukäsikirja antaa työkalun toiminnan kehittämiseen. Käsikirja pohjautuu konsulttiyrityksen liiketoiminnan näkemiseen asiakkaalle lisäarvoa tuottavina prosesseina, joiden hallinta luo edellytykset kannattavalle liiketoiminnalle. Laatukäsikirja rakentuu minimivaatimuksille, jotka kunkin konsultin tai konsulttiorganisaation tulee täyttää. Laatukäsikirjassa noudatetut periaatteet ovat yhdenmukaisia muun muassa laatupalkintokriteeristön, ISO 9000 laatustandardien sekä konsulttien kansainvälisen CMC-kriteeristön kanssa. CMC ( Certified Management Consultant ) on kansainvälisen ICMCI:n ( The International Council of Management Consulting Institutes ) vakiinnuttama nimeke. Sen käyttöoikeus myönnetään yksittäisille liikkeenjohdon konsulteille, jotka läpäisevät erityisen sertifiointiohjelman. CMC -sertifiointiohjelman organisoi Suomessa Liikkeenjohdon Konsultit LJK ry ja Helsingin kauppakorkeakoulun johtamisen laitos vastaa ohjelman suunnittelusta ja toteutuksesta. CMC-ohjelma on asemoitu PKT-säätiön järjestämän laatukoulutuksen täydennykseksi.

Konsultoinnin toimialatutkimuksen professiopalvelujen arvoketjussa alan yrityksen sisäiset toiminnot ja prosessit käsittävät tuotekehittelyn ja markkinoinnin. Käytäntöön sovellettuna PKT-säätiö pyrkii seuraamaan myös menetelmäkehityksen osalta yliopistojen ja korkeakoulujen hankkeita, jotka liittyvät liikkeenjohdon konsultointiin. GUIDELINE ( Dynamic Guidelines for SMEs in Europe to Manage Change in a Turbulent Environment) on EUREKA-statuksen omaava tutkimushanke, joka on Teknillisen Korkeakoulun TAI-tutkimuslaitoksen ja Saksalaisen Fraunhofer-instituu- tin yhteisprojekti. Projektin tavoitteena on kehittää menetelmiä ja työkaluja, joiden avulla yritykset voivat seurata nopeasti muuttuvaa toimintaympäristöään ja käynnistää kehitystoimia muutosten vaatimaan suuntaan. Tavoitteena on luoda menetelmä, jossa konsultti ja yritys yhteisen koulutusosion jälkeen voivat soveltaa menetelmää yrityksen muutosprosessissa.

\section{ENNAKOINNILLA VALMISTAUDUTAAN MUUTOKSIIN}

Liikkeenjohdon konsultoinnin toimialatutkimuksen mukaan alalle tulon ja sieltä poistumisen virtaus on erittäin voimakas. Markkinasuojan puuttumisesta konsultoinnissa on herännyt vilkas ja monitasoinen keskustelu niin konsulttien ja toimeksiantajien kuin esimerkiksi alan kouluttajien keskuudessa. Toisaalta pohditaan syitä alalle ryhtymiseen, toisaalta taas syitä poistumaan. Alalta poistuma voi tarkoittaa konsulttiyrityksen lopettamista, mutta myös konsulttitoiminnan jatkamista jonkun muun palveluksessa. Voimakkainta virtaus tietysti on kaikkein pienimmässä konsulttiyrityskoossa. Mielenkiintoinen keskustelu on syntynyt myös konsultoinnin koulutusta järjestävissä organisaatioissa. On muun muassa pohdittu, voisiko koulutuksellisin keinoin lisätä vakautta alalla. Usein keskustelussa konsultoinnista unohdetaan, että lukumääräisesti ehdottomasti suurin osa konsulteista on itsekin pk-yrittäjiä. Pk-konsulttiyrityksiin on siis liitettävissä myös muuta pk-sektoria koskevaa tutkimusaineistoa.

Koska toimialan rakenteiden ja markkinoiden tunteminen on keskeinen osa alan kehityksessä, on välttämätöntä uusia tutkimus aika ajoin. Keväällä 1999 tehdään uusi kyselytutkimus, jolla päivitetään vuonna 1995 tehty tutkimus. Vertailukelpoisuuden säilyttämiseksi pyritään kysely pitämään pääsääntöisesti samansisältöisenä. Tavoitteena on levittää kysely myös ulkomaisten yhteistyökumppaneiden toteutettavaksi. Alustavia keskusteluja tutkimuksen toteuttamisesta on käyty sekä CESCE:n jäsenjärjestöjen että pohjoismaisten yhteistyöorganisaatioiden kanssa. 
Helsingin yliopiston Aikuiskoulutuskeskuksen vuonna 1997 toteuttamaProfdelfi-projekti selvitti asiantuntijapalvelusektorin tulevaisuutta ja asiantuntijapalveluyrityksissä työskentelevien akateemisten henkilöiden tulevaisuuden osaamistarpeita. Asiantuntijatyössä ennakoidut muutokset liittyvät lähinnä informaatioteknologian, työaikojen joustavuuden ja työn projektimaisuuden lisääntymiseen. Esiin nousi myös kysymys asiantuntijatyötä tekevien henkisestä jaksamisesta. Viiden vuoden aikaperspektiivillä tarkasteltuna asiantuntijapalvelujen tulevaisuus näyttää kuitenkin valoisalta. Ongelmia Profdelfin mukaan voi syntyä asiantuntijapalveluiden heikosta käyttötaidosta ja yritysten kehittämistarpeiden hahmottamisen vaikeudesta. (Profdelfistä tarkemmin Jari Lindqvistin ja Jyri Mannisen artikkelissa tässä numerossa)

PKT-säätiö käynnisti vuonna 1998 Euroopan sosiaalirahaston osittain rahoittaman projektin nimellä QUALICON Liikkeenjohdon konsulttien laadullinen ja määrällinen ennakointihanke. Hankkeen eräänä tavoitteena on selvittää, minkälaisia konsultteja ja missä määrin tulevaisuudessa tarvitaan ja toisaalta, mikä on konsultin rooli ja profiili elinkeinoelämän muutosten vaikutuksesta ja minkälaista koulutusta ja valmennusta konsultti tarvitsee.

\section{HYVÄT KONSULTTIHANKKEET KANNUSTAVAT}

Yrittäjien omakohtaiset kokemukset konsultinkäytöstä ja muiden yrittäjien kertomukset omista konsultointihankkeistaan ovat merkittäviä tekijöitä edistettäessä ulkopuolisten asiantuntijoiden käyttöä. Asenteet ja ennakkokäsitykset muovautuvat usein sen mukaan, minkälaisia kokemuksia yrittäjällä itsellään tai hänen lähipiirissään on ollut. Hyvin usein on helpompaa puhua epäonnistuneista konsultointihankkeista kuin kertoa onnistumisista, jolloin altistutaan yrityssalaisuuksien paljastamisen alueelle tai herätetään kateutta.

Konsultoinnin onnistumista on hyvin vaikea mitata; silloin täytyy paneutua tarkasti molempien osapuolien suorituksiin ja vaikutuksiin hankkeen valmistelussa ja toteuttamisessa. Yritykset elävät jatkuvassa vuorovaikutuksessa ympäristönsä kanssa, jolloin on vaikeaa - joskus jopa mahdotonta erottaa pelkästään konsultoinnilla aikaan saadut tulokset.

PKT-säätiö järjestää vuosittain kilpailun liikkeenjohdon konsulttiyritykselle. Tarkoituksena on tuoda esiin hyviä, onnistuneita konsultointitöitä, jotka voivat selventää konsultoinnin olemusta yrityksille, jotka eivät ole käyttäneet konsulttia tai ovat siinä epäonnistuneet. Konsultin ja toimeksiantajan yhteistyö ja roolien selvittäminen on erittäin tärkeää konsultoinnin onnistumisen kannalta. Kilpailulla halutaan myös tuoda esiin käytännön esimerkein liikkeenjohdon konsultointialan monimuotoisuutta. On tärkeää nähdä konsultointi myös kokonaisuutena, jonka osia ovat konsultti tai konsulttitiimi, konsultointiin osallistuvat yrityksen edustajat sekä yrityksen ympäristö.

Konsulttitietokanta: www.pkt.fi $\longrightarrow$ (suomi) $\longrightarrow \mathrm{KoRe} \longrightarrow$ 